\title{
PENGARUH KUALIFIKASI PENDIDIKAN TERHADAP PENGETAHUAN GURU MATEMATIKA DALAM MENYUSUN RENCANA PELAKSANAAN PEMBELAJARAN
}

\author{
R Bambang Aryan Soekisno', Rafiq Zulkarnaen ${ }^{2}$ \\ 1 SMA Negeri 1 Bogor, JI. IR. H. Juanda No.16, Kota Bogor, Indonesia \\ 2 Universitas Singaperbangsa Karawang, J. HS Ronggowaluyo Teluk Jambe, Kabupaten Karawang, Indonesia \\ Email: 'bambang_aryan@yahoo.com, 2rafiq.zulkarnaen@fkip.unsika.ac.id
}

\begin{abstract}
Lesson plans are an important thing in teaching mathematics that requires several components including mathematical and pedagogical knowledge. The quality of lesson plans carried out by teachers is very much built on educational qualifications and teaching experience. This research was conducted to focus on answering the questions of whether educational qualifications and length of teaching processes influence the ability of mathematics teachers in preparing lesson plans and how the quality of mathematics teachers' knowledge is in formulating lesson plans. The case study used in this research is with single and multiple analyses. The case observed in this study is the ability of mathematics teachers in preparing lesson plans in terms of educational qualifications and length of teaching, as well as teachers' mathematical knowledge in compiling lesson plans. The research subjects were 69 mathematics teachers in Bogor City, West Java Province. Educational qualifications are divided into three criteria, namely: Bachelor of Mathematics Education, Non-Mathematics Education Degree, and Non-Education Bachelor. In addition to educational qualifications, it is also reviewed from years of teaching experience. The test and non-test instruments were used in this study, the test instruments for the preparation of RPP by SP on KD 3.3 and 4.3 on the SPLDV material, while the non-test instruments were in the form of interviews and observations. The conclusion in this research that preparing lesson plans could not be relied on by length of teaching, but very reliable by educational qualifications, and educational qualifications had a significant impact on teachers' mathematical knowledge.
\end{abstract}

Keywords: Doing mathematics, pedagogical-didactical anticipation, mathematics content knowledge, pedagogical knowledge, lesson plans

\begin{abstract}
ABSTRAK
Perencanaan pelaksanaan pembelajaran sebagai proses penting dalam mengajar matematika, dalam penyusunan perencanaan pembelajaran melibatkan beberapa komponen diantaranya pengetahuan konten matematika dan pengetahuan pedagogis. Kualitas penyusunan rencana pelaksanaan pembelajaran yang dilakukan oleh guru sangat dipengaruhi oleh kualifikasi pendidikan dan pengalaman mengajar. Tujuan penelitian ini yaitu: (a) mengetahui pengaruh kualifikasi pendidikan dan lama mengajar terhadap kemampuan guru matematika dalam menyusun Rencana Pelaksanaan Pembelajaran (RPP); dan (b) mengetahui kualitas pengetahuan guru matematika dalam merumuskan RPP. Studi kasus yang digunakan dalam penelitian ini yaitu kasus tunggal dan analisis ganda. Kasus yang diamati dalam penelitian ini yaitu kemampuan guru matematika dalam menyusun RPP ditinjau dari kualifikasi pendidikan dan lama mengajar, serta pengetahuan matematika guru dalam menyusun RPP. Subjek penelitian sebanyak 69 guru matematika di Kota Bogor Provinsi Jawa Barat. Kualifikasi pendidikan dibagi kedalam tiga kriteria, yaitu: Sarjana Pendidikan Matematika, Sarjana non-Pendidikan Matematika, dan Sarjana non-Pendidikan. Selain kualifikasi pendidikan, ditinjau juga dari lama mengajar. Instrumen yang digunakan dalam penelitian ini terdiri dari instrumen tes dan non tes. Instrumen tes berbentuk penyusunan RPP oleh SP pada KD 3.3 dan 4.3 pada materi SPLDV, sedangkan instrumen non tes berbentuk wawancara dan observasi. Simpulan yang diperoleh dari penelitian ini adalah kemampuan menyusun RPP tidak dipengaruhi oleh lama mengajar, namun sangat dipengaruhi oleh kualifikasi pendidikan, dan kualifikasi pendidikan memberikan dampak secara signifikan tehadap pengetahuan guru matematika.
\end{abstract}

Kata kunci: Aktivitas matematis, antisipasi pedagogis-didaktis, pengetahuan konten matematika, pengetahuan pedagogis, RPP

Dikirim: 31 Mei 2021; Diterima: 31 Agustus 2021; Dipublikasikan: 30 September 2021

Cara sitasi: Soekisno, R. B. A., \& Zulkarnaen, R. (2021). Pengaruh kualifikasi pendidikan terhadap pengetahuan matematika guru dalam menyusun rencana pelaksanaan pembelajaran. Teorema: Teori dan Riset Matematika, 6(2), 184-197. DOl: http://dx.doi.org/10.25157/teorema.v6i2.5426 


\section{PENDAHULUAN}

Kualitas guru dalam mengajar matematika yang efektif sangat dipengaruhi oleh beberapa faktor, diantaranya: kualifikasi pendidikan, pengalaman mengajar matematika (lama mengajar), pelatihan, bakat, dan motivasi. Kualifikasi pendidikan guru dan lama mengajar matematika di sekolah dalam menyusun Rencana Pelaksanaan Pembelajaran (RPP) merupakan fokus kajian dalam penelitian ini. Guru matematika idealnya memiliki kualifikasi pendidikan matematika, namun kenyataan di lapangan masih ditemukan guru yang mengajar matematika tidak memiliki kualifikasi sarjana pendidikan matematika. Selanjutnya, lama mengajar memberikan pengalaman yang berharga kepada guru dalam menyusun RPP yang baik dan berkualitas. Pengalaman dalam bentuk kesulitan menyusun RPP, adaptasi pelaksanaan pembelajaran yang tidak sesuai dengan praktiknya di kelas, dan perbaikan RPP sesuai dengan kebutuhan materi dan siswa serta perkembangan kurikulum matematika.

Perencanaan pelaksanaan pembelajaran sebagai proses penting dalam mengajar, karena merupakan fokus utama dalam mempelajari bagaimana cara mengajar yang akan dilakukan oleh guru (Norman, 2011). Namun demikian, ketika para pemula (calon guru) menghadapi kerumitan perencanaan, mereka membutuhkan lebih banyak pembekalan kurikuler dan bantuan terstruktur (Kauffman et al., 2002). Pembekalan kurikuler dan bantuan terstruktur dalam menyusun pelaksanaan pembelajaran didapatkan oleh pemula (calon guru atau sarjana pendidikan) melalui pembelajaran di Lembaga Pendidik Tenaga Kependidikan (LPTK) baik secara teoritis maupun praktik dalam program pendidikan latihan profesi atau program magang di sekolah, yang bertujuan untuk mengintegrasikan teoritik dan praktik dalam perencanaan pelaksanaan pembelajaran. Oleh karenanya mengapa perencanaan pelajaran diidentifikasi dalam standar persiapan guru di LPTK, serta standar sertifikasi guru dan standar terkait lainnya untuk pengajaran (Norman, 2011). Calon guru (sarjana pendidikan) di LPTK ditempatkan dalam posisi praktis untuk terlibat dalam belajar tentang bagaimana cara mengajar, serta memahami kesulitan dalam mengajarkan materi kepada siswa. Dalam konteks penelitian ini, peneliti menduga bahwa kemampuan guru dalam menyusun perencanaan pelaksanaan pembelajaran sangat dipengaruhi oleh kualifikasi pendidikan (sarjana pendidikan). Selanjutnya, dalam perencanaan pelaksanaan pembelajaran matematika memuat pengetahuan materi matematika yang diperlukan untuk mengajar. Oleh karenanya dalam konteks penelitian ini, peneliti menduga bahwa kualitas perencanaan pelaksanaan pembelajaran yang disusun oleh sarjana pendidikan matematika lebih baik dibandingkan dengan sarjana pendidikan di luar pendidikan matematika; dan, penyusunan pelaksanaan pembelajaran yang efektif tidak dipengaruhi oleh pengalaman (lama mengajar guru) melainkan dari kualifikasi pendidikan.

Untuk menjalankan aktivitas guru matematika yang profesional, guru membutuhkan keterampilan kognitif (Döhrmann et al., 2012). Tiga domain kognitif yang diperlukan oleh guru yaitu knowing, applying, dan reasoning (Tatto et al., 2008). Aspek knowing meliputi berbagai kemampuan seperti mengingat definisi dan sifat-sifatnya, mengenali dan mengklasifikasikan objek matematika, menjalankan prosedur algoritmik, memberikan interpretasi gambar dan tabel, dan menggunakan alat ukur; aspek applying mengacu pada kemampuan guru dalam memilih prosedur penyelesaian yang efisien, metode atau strategi dalam memecahkan masalah, menghasilkan dan menerapkan model matematis yang sesuai dengan situasi masalah dunia nyata, dan merepresentasikan informasi dan data dalam diagram dan tabel; dan, aspek reasoning mencakup kemampuan untuk membuktikan dan bernalar secara matematis dan untuk menganalisis dan mengkarakterisasi hubungan matematis (Döhrmann et al., 2012). Dengan demikian, kemampuan kognitif yang diperlukan oleh guru sangat berkaitan erat dengan pengetahuan matematika yang dimiliki oleh guru. Pengetahuan matematika yang dimiliki oleh guru tidaklah bersifat instan melainkan dihasilkan dari pendidikan formal calon guru matematika. Dalam konteks penelitian ini, peneliti menduga bahwa kemampuan guru dalam aspek mengidentifikasi materi matematika dan penerapan kegiatan pembelajaran yang memuat aktitivas matematis sebagai bagian dalam merencanakan pembelajaran matematika yang efektif 
sangat dipengaruhi oleh kualifikasi pendidikan (sarjana pendidikan matematika) dibandingkan dengan pengalaman (lama mengajar).

Merencanakan pelajaran adalah bagian penting dari mengajar matematika, dan untuk melaksanakan tugas mengajar matematika secara efektif guru harus memiliki Pengetahuan Matematika untuk Guru. Ball et al., (2008) mengemukakan bahwa Pengetahuan Matematika Guru (disingkat, PMG) meliputi: Pengetahuan Konten umum (disingkat, PKU), Pengetahuan Konten Khusus (disingkat, PKK), Pengetahuan Konten Horizon (disingkat, PKoH), Pengetahuan Matematika Siswa (disingkat, PMS), Pengetahuan tentang Materi Matematika (disingkat, PtMM), dan Pengetahuan tentang Matematika dan Kurikulum (disingkat, PtMK). PKU adalah pengetahuan dan keterampilan matematika yang tidak secara khusus berkaitan dengan mengajar, sebagai contoh: Mengetahui 12 adalah jawaban yang benar dari 91 dikurangi dari 79; PKK adalah pengetahuan dan keterampilan matematika yang diperlukan dalam mengajar, sebagai contoh: mengetahui bahwa 91 dikurangi 79 dapat diselesaikan dengan cara "11-9 + 80-70," "91-80 + 1," atau "1 + 90-80 + 1"; $\mathrm{PkoH}$ adalah pengetahuan matematika dikaitkan dengan topik matematika di sekolah, sebagai contoh: mengetahui bagaimana mengajarkan pengurangan dua digit seperti "91-79" berhubungan dengan pengurangan satu digit dari pengurangan dua digit dan / atau beberapa digit; PMS adalah pengetahuan tentang bagaimana siswa memikirkan dan menginterpretasikan matematika, sebagai contoh: mengantisipasi respon dan kesulitan siswa yang berbeda dalam melakukan pengurangan dengan "91-79"; PtMM adalah pengetahuan tentang apa dan bagaimana guru mengurutkan matematika dan kegiatan pembelajaran, sebagai contoh: memutuskan cara mengajarkan "91-79" yang mana hendaknya dibahas terlebih dahulu di kelas dan apa yang akan ditempatkan berikutnya; PtMK adalah pengetahuan matematika yang berkaitan dengan persyaratan kurikulum, sebagai contoh: tujuan pembelajaran dari pengurangan dua digit yang termuat dalam kurikulum (Chen \& Zhang, 2019).

PtMT dan PtMK sangat diperlukan oleh guru dalam pengembangan profesionalnya dan mempersiapkan rencana pembelajaran matematika yang akan dilakukan (Campbell et al., 2014) pengetahuan matematika guru yang rendah sangat dipengaruhi oleh pengalaman belajar matematika ketika masih menjadi mahasiswa calon guru (Norton, 2019), dan PMG yang diperoleh selama perkuliahan memberikan dampak terhadap pemahaman konseptual guru yang akan diajarkan kepada siswa (Bowie et al., 2019). Oleh karenanya, diduga bahwa guru yang mengajar matematika di sekolah dengan kualifikasi bukan sarjana pendidikan matematika memiliki PMG yang rendah. Beberapa penelitian yang relevan dengan penelitian ini menunjukkan bahwa guru matematika masih lemah dalam menyusun RPP diantaranya: Siregar (2019), Hartini (2021), dan Herdawati et al., (2019), namun ketiga penelitian tersebut tidak memperhatikan lama mengajar guru matematika dan membandingkan kualifikasi pendidikan karena kenyataan di lapangan masih ditemukan guru yang mengajar matematika bukan berasal dari sarjana pendidikan matematika (kualifikasi pendidikan).

Berdasarkan uraian yang telah dikemukakan di atas, penelitian ini difokuskan untuk menjawab pertanyaan pengaruh kualifikasi pendidikan dan lama mengajar memberikan pengaruh terhadap kemampuan guru matematika dalam menyusun RPP? Bagaimana kualitas pengetahuan matematika guru dalam merumuskan RPP?.

\section{METODE PENELITIAN}

Studi kasus dengan kasus tunggal dan analisis ganda (Yin, 2018) digunakan dalam penelitian ini. Kasus yang diamati yaitu kemampuan guru matematika dalam menyusun RPP ditinjau dari kualifikasi pendidikan dan lama mengajar, dan pengetahuan matematika guru (disingkat, PMG) dalam menyusun RPP. Subjek penelitian (disingkat, SP) sebanyak 69 guru matematika di Kota Bogor, Provinsi Jawa Barat. Kualifikasi pendidikan dibagi kedalam tiga kriteria, yaitu: Sarjana Pendidikan Matematika (Kode, SPM), Sarjana non-Pendidikan Matematika dengan bidang studi yang masih satu rumpun dengan pendidikan matematika (Kode, SPnM), misalnya: Sarjana 
Matematika; Sarjana non-Pendidikan (Kode, SnP), misalnya sarjana lingkungan hidup, dan sarjana manajemen pendidikan. Pengelompokan SP kedalam tiga kategori disebabkan hasil identifikasi yang menemukan SP dengan kualifikasi pendidikan yang beragam. Selain kualifikasi pendidikan, ditinjau juga dari lama mengajar. Lama mengajar dibagi kedalam tiga kriteria, yaitu: lama mengajar kurang dari lima tahun (Kode, A), lama mengajar diantara lima sampai 10 tahun (Kode, B), dan lama mengajar lebih dari 10 tahun (Kode, C). Sebaran SP ditinjau dari kualifikasi pendidikan dan lama mengajar disajikan pada Tabel 1.

Tabel 1. Sebaran SP ditinjau dari kualifikasi pendidikan dan lama mengajar

\begin{tabular}{cccc}
\hline \multirow{2}{*}{ Kualifikasi pendidikan } & \multicolumn{3}{c}{ Lama mengajar } \\
\cline { 2 - 4 } & $\mathrm{A}$ & $\mathrm{B}$ & $\mathrm{C}$ \\
\hline SPM & 10 & 25 & 17 \\
\hline SPnM & - & 2 & 13 \\
\hline SnP & - & - & 2 \\
\hline
\end{tabular}

Penelitian diawali dengan meminta SP untuk menyusun RPP pada kompetensi dasar (disingkat, KD) untuk aspek pengetahuan dan keterampilan, yaitu: Mendeskripsikan konsep sistem persamaan linier dan kuadrat dua variabel dan memilih metode yang efektif untuk menentukan himpunan penyelesaiannya (pada KD.3.3); dan, Memecahkan hasil pemecahan masalah nyata sebagai terapan konsep dan aturan penyelesaian SPLKDV (KD 4.3). Penyusunan RPP pada KD 3.3 dan 4.3 dilakukan oleh SP selama 60 menit, kemudian dilakukan analisis komponen dalam RPP, yaitu: tujuan pembelajaran (meliputi: indikator pembelajaran, penggunaan kata kerja operasional, dan cara merumuskan indikator pembelajaran), materi pembelajaran (meliputi: kesesuaian materi dengan KD dan indikator pembelajaran, dengan kemampuan siswa, urutan materi dan kelengkapannya), kegiatan pembelajaran (meliputi: ketepatan pemilihan model/ pendekatan pembelajaran, sintaks pembelajaran, tahapan kegiatan pembelajaran, dan penerapan pengalaman pembelajaran), dan evaluasi (meliputi: kesesuaian evaluasi dengan tujuan pembelajaran, cakupan evaluasi, dan kelengkapan komponen evaluasi). Selain itu, dilakukan pengamatan PMG yang dimiliki SP ketika menyusun RPP.

Tabel 2. Pedoman penskoran RPP

\begin{tabular}{llc}
\hline \multicolumn{1}{c}{ Aspek } & \multicolumn{1}{c}{ Subaspek } & SMI \\
\hline Tujuan & & 2 \\
pembelajaran & Indikator pembelajaran & 3 \\
\cline { 2 - 3 } & Penggunaan kata kerja operasional dalam indikator secara spesifik, terukur, dan teramati & 3 \\
\cline { 2 - 3 } Materi & Cara merumuskan indikator pembelajaran & 2 \\
\cline { 2 - 3 } & Kesesuaian materi yang akan diajarkan dengan kompetensi dasar dan indikator & 2 \\
\cline { 2 - 3 } & Kesesuaian materi dengan tingkat kemampuan siswa & 2 \\
\hline Kegiatan & Krutan penyajian materi & 2 \\
\cline { 2 - 3 } pembelajaran & Sintaks Pembelajaran & 2 \\
\cline { 2 - 3 } & Tahapan kegiatan pembelajaran & 2 \\
\cline { 2 - 3 } & Penerapan pengalaman pembelajaran & 2 \\
\hline Evaluasi & Kesesuaian evaluasi dengan tujuan pembelajaran & 2 \\
\cline { 2 - 3 } & Cakupan evaluasi & 2 \\
\cline { 2 - 3 } & Kelengkapan evaluasi & 2 \\
\hline
\end{tabular}

SMI adalah Skor Maksimal Ideal

Tabel 2 merupakan pedoman penskoran RPP dan digunakan untuk mengidentifikasi kemampuan SP dalam menyusun RPP. Misalkan hasil analisis RPP yang disusun oleh SP pada aspek tujuan pembelajaran dengan subaspek penggunaan kata kerja operasional yang teridentifikasi paling tidak ada satu indikator yang operasional yang dapat diamati dan diukur, maka diberi skor 2.

Analisis penyusunan RPP pada masing-masing komponen yang telah disusun oleh SP, kemudian dilakukan analisis secara kuantitatif dan kualitatif. Pemberian skor terhadap RPP yang telah disusun oleh SP merupakan data kuantitatif yang harus dianalisis, sedangkan data kualitatif merupakan komponen pendukung yang tak terpisahkan untuk menghasilkan eksplanasi teoritis terhadap kasus yang diamati melalui wawancara dan observasi. 


\section{HASIL DAN PEMBAHASAN}

Secara umum persentase rerata skor dengan skor maksimal ideal (disingkat, SMI) penilaian RPP untuk aspek tujuan, materi, kegiatan, dan evaluasi pembelajaran pada setiap kategori subjek penelitian (kualifikasi pendidikan dan lama mengajar disajikan pada Gambar 1.

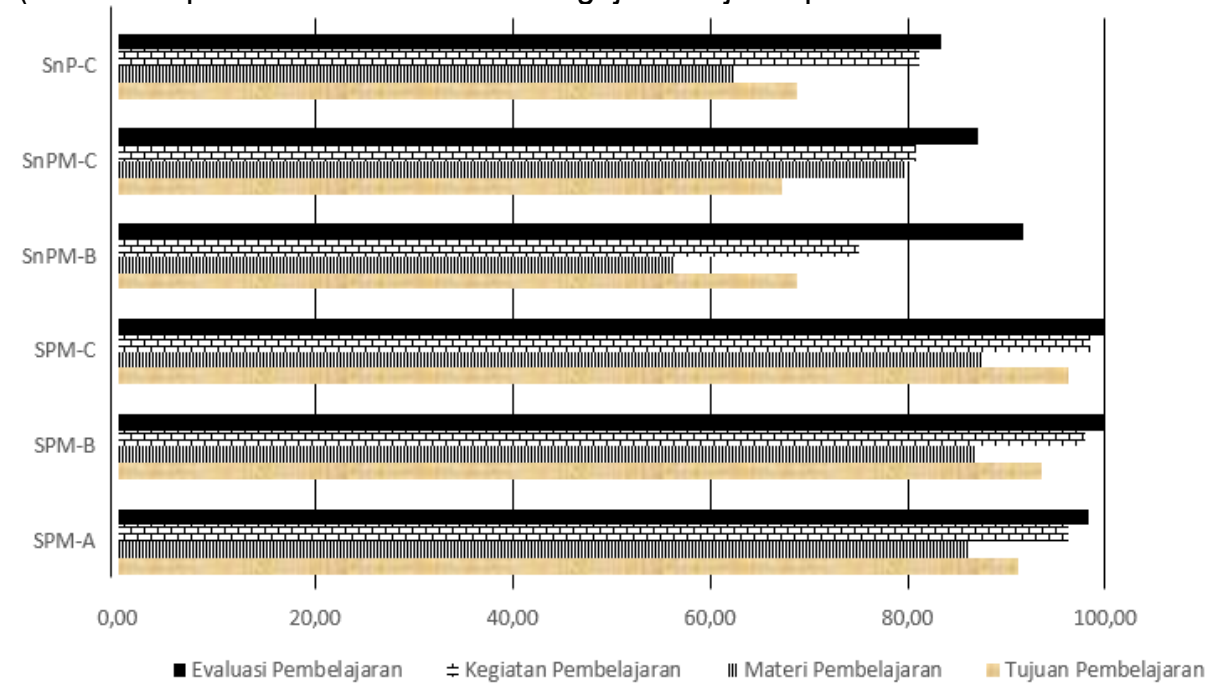

Gambar 1. Persentase skor RPP pada semua kategori subjek penelitian

Berdasarkan Gambar 1 ditinjau dari kualifikasi pendidikan, kemampuan SPM dalam menyusun rencana pelaksanaan pembelajaran cenderung lebih baik dibandingkan SnPM dan SnP, dengan pencapaian rerata skor lebih dari $85 \%$ SMI. Selanjutnya ditinjau dari kualifikasi pendidikan dan lama mengajar, pencapaian rerata skor penyusunan RPP SPM-A, SPM-B, dan SPM-C cenderung lebih baik dari SnPM-B, SnPM-C, dan SnP-C. Temuan tersebut mengindikasikan bahwa kemampuan menyusun RPP tidak dipengaruhi oleh lama mengajar, namun sangat dipengaruhi oleh kualifikasi pendidikan. Salah satu kompetensi yang harus dimiliki oleh guru adalah kemampuan dalam merumuskan RPP. Kemampuan dalam menyusun RPP harus dipelajari oleh calon guru matematika atau mahasiswa program studi pendidikan matematika (latar belakang SPM) melalui perkuliahan baik teoritis maupun praktis. Teori-teori belajar, pengetahuan matematika persekolahan dan untuk kepentingan studi lanjut harus dimplementasikan ke dalam praktek pembelajaran, dimulai tahapan pendahuluan sampai penutup (Aminah, 2014). Dengan demikian, faktor lama mengajar (pengalaman mengajar) tidak berbanding lurus dengan kemampuan subjek dalam merumuskan tujuan pembelajaran, penyusunan materi pembelajaran, dan merumuskan kegiatan pembelajaran.

Analisis penyusunan RPP pada masing-masing aspek dan subaspeknya yang dilakukan oleh subjek penelitian ditinjau dari kualifikasi pendidikan dan lama mengajar diuraikan berikut.

\section{Komponen RPP Aspek Tujuan Pembelajaran}

Analisis RPP pada aspek tujuan pembelajaran yang telah disusun oleh subjek penelitan disajikan pada Tabel 2.

Tabel 2. Analisis RPP pada Aspek Tujuan Pembelajaran

\begin{tabular}{|c|c|c|c|c|c|c|c|}
\hline \multirow[b]{2}{*}{ Subaspek } & \multirow{2}{*}{$\begin{array}{c}\text { Skor } \\
\text { Maksimal } \\
\text { Ideal } \\
\text { (SMI) }\end{array}$} & \multicolumn{6}{|c|}{ Rerata Skor } \\
\hline & & SPM-A & SPM-B & SPM-C & SPnM-B & SPnM-C & SnP-C \\
\hline Indikator Pembelajaran (IP) & 2 & 1,80 & 1,84 & 2,00 & 2,00 & 1,77 & 2,00 \\
\hline $\begin{array}{l}\text { Penggunaan Kata kerja operasional } \\
\text { dalam indikator secara spesifik, } \\
\text { terukur, dan teramati (PKKO) }\end{array}$ & 3 & 2,60 & 2,60 & 2,76 & 2,00 & 2,00 & 2,00 \\
\hline $\begin{array}{lr}\text { Cara merumuskan indikator } \\
\text { Pembelajaran }(A B C D)\end{array}$ & 3 & 2,80 & 2,88 & 2,94 & 2,00 & 2,15 & 2,50 \\
\hline
\end{tabular}


Berdasarkan Tabel 2 terlihat bahwa SP tidak kesulitan dalam merumuskan indikator pembelajaran (IP), hal ini dapat diamati dari persentase rerata skor IP di atas 85\% SMI. Namun demikian, masih ditemukan SP kesulitan dalam penggunaan kata kerja operasional (PKKO) dan cara merumuskan indikator pembelajaran yang memuat Audience, Behavior, Condition dan Degree (ABCD). Hal tersebut dapat diamati dari subjek dengan kode SPnM-B, SPnM-C, dan SnP-C presentasi rerata skor dengan SMI untuk PKKO dan ABCD di bawah 85\%. Kesulitan dalam PKKO dan ABCD tidak terjadi pada SP dengan kode SPM (guru matematika dengan kualifikasi sarjana pendidikan matematika), hal ini dapat diamati dari persentasi serta SPM dengan SMI untuk PKKO dan ABCD di atas $85 \%$ dari SMI. Lemahnya kemampuan subjek penelitian dalam menyusun RPP pada aspek penyusunan tujuan pembelajaran dengan subaspek IP, PKKO dan ABCD sejalan dengan hasil penelitian Hidayat (2020), Alhikmah et al., (2021). Guru mengalami kesulitan dalam menyusun IP yang diturunkan dari KD (Hidayat, 2020); Guru belum mampu menerapkan kata kerja operasional yang memperhatikan syarat ABCD (Alhikmah et al., 2021).

Pengalaman belajar SPM ketika menjadi mahasiswa prodi pendidikan matematika yang dibekali dengan pengetahuan dan keterampilan dalam mata kuliah dasar keguruan (MKDK), misalnya mata kuliah kurikulum dan pembelajaran memberikan dampak secara nyata dalam penyusunan tujuan pembelajaran, khususnya pada penyusunan indikator pembelajaran menggunakan KKO yang sesuai $A B C D$. KKO merupakan suatu kata kerja yang menggambarkan aktivitas dalam dimensi proses pembelajaran yang disesuaikan dengan Taksonomi Bloom yang direvisi oleh Anderson. Penggunaan KKO yang sesuai ABCD memberikan petunjuk kepada SPM dalam menyusun indikator pembelajaran bersifat operasional yang dapat diamati dan diukur sesuai dengan kompetensi dasar.

\section{Komponen RPP Aspek Materi Pembelajaran}

Analisis RPP pada aspek materi pembelajaran yang telah disusun oleh subjek penelitan disajikan pada Tabel 3.

Tabel 3. Analisis RPP pada aspek materi pembelajaran

\begin{tabular}{|c|c|c|c|c|c|c|c|}
\hline \multirow[b]{2}{*}{ Subaspek } & \multirow{2}{*}{$\begin{array}{c}\text { Skor } \\
\text { Maksimal } \\
\text { Ideal (SMI) }\end{array}$} & \multicolumn{6}{|c|}{ Rerata skor } \\
\hline & & SPM-A & SPM-B & SPM-C & SPnM-B & SPnM-C & SnP-C \\
\hline $\begin{array}{l}\text { Kesesuaian materi yang akan } \\
\text { diajarkan dengan kompetensi } \\
\text { dasar dan indikator (KMIP) }\end{array}$ & 2 & 2,00 & 2,00 & 2,00 & 1,50 & 1,85 & 2,00 \\
\hline $\begin{array}{l}\text { Kesesuaian materi dengan } \\
\text { kemampuan siswa (KMKS) }\end{array}$ & 2 & 1,70 & 1,80 & 1,71 & 1,00 & 1,62 & 1,00 \\
\hline Urutan materi (UM) & 2 & 1,60 & 1,64 & 1,71 & 1,00 & 1,54 & 1,00 \\
\hline Kelengkapan materi (KM) & 2 & 1,60 & 1,52 & 1,59 & 1,00 & 1,38 & 1,00 \\
\hline
\end{tabular}

Pada subaspek kesesuaian materi dengan materi yang akan diajarkan dengan kompetensi dasar dan indikator (KMIP), hampir semua subjek memperoleh pencapaian skor di atas $85 \%$ dari SMI kecuali pada SPnM-B (Sarjana non-Pendidikan Matematika dengan bidang studi yang masih satu rumpun dengan pendidikan matematika dengan lama mengajar diantara 5 sampai 10 tahun). Namun demikian, pada subaspek KMKS, UM, dan KM pencapaian skor di atas $85 \%$ dari SMI hanya diperoleh subjek dengan kualifikasi Sarjana Pendidikan Matematika pada semua kategori lama mengajar (SPM-A, SPM-B, dan SPM-C). Secara keseluruhan, penyusunan RPP pada aspek materi pembelajaran dalam semua subaspek KMIP, KMKS, UM, dan KM subjek penelitian dengan kode SPM memiliki pengetahuan materi matematika yang sangat mumpuni. Pengetahuan materi matematika (PMM) merupakan pengetahuan yang harus kuasai oleh guru. PMM yang diperoleh oleh SPM disebabkan latar belakang pendidikan (sarjana pendidikan) yang memberikan pengalaman belajar dalam mata kuliah keilmuan dan keterampilan di LPTK, misalnya: kapita selekta matematika. Pengalaman SPM dalam perkuliahan MKK memberikan kontribusi terhadap merumuskan objek matematika (fakta, prisip, konsep, dan prosedur) dengan baik, mengurutkan materi dari sederhana/ 
mudah sampai kepada kompleks/ sulit, dan keterkaitan antar topik dalam matematika. Selain itu, pengalaman SPM dalam mata kuliah dasar keahlian (MKDK) atau kelompok mata kuliah yang bertujuan memberikan landasan pembentukan keahlian atau pengembangan profesi, misalnya: mata kuliah evaluasi pembelajaran, strategi belajar mengajar matematika. Pengalaman SPM dalam MKK dan MKDK mampu memberikan kontribusi terhadap penyesuaian materi dengan kemampuan siswa (KMKS), urutan materi (UM), dan kelengkapan materi (KM).

Tabel 3 menunjukkan subjek penelitian yang tidak berkualifikasi sarjana pendidikan matematika (SPnM dan SnP) memiliki kesulitan dalam KMKS, UM, dan KM yang disebabkan pemahaman atau pengetahuan matematika yang kurang mumpuni. Semakin dalam pemahaman guru tentang matematika, akan mengakibatkan guru melibatkan siswanya untuk berpikir secara produktif tentang sifat konseptual dari mata pelajaran matematika (Fennema \& Franke dalam Osana et al., 2006). Pemilihan materi yang sesuai dalam pembuatan tugas oleh guru memiliki dampak terbesar pada pembelajaran dan persepsi siswa terhadap matematika (Lappan \& Friel, 1993). Lebih lanjut, tanpa pemahaman matematika yang mendalam, seorang guru tidak dapat secara efektif terlibat dalam kegiatan pembelajaran yang merupakan inti dari guru profesional, seperti memilih tugas yang sesuai untuk siswa, memprediksi kesulitan siswa, dan merepresentasikan konsep dengan cara berbeda yang akan meningkatkan kemampuan pemahaman matematis siswa (Osana et al., 2006). Membuat keputusan tentang kegiatan pembelajaran melalui identifikasi materi dan aktivitas siswa merupakan bagian dari profesionalisme guru. Pengembangan profesionalisme guru matematika sangat dipengaruhi oleh pengalaman belajar di program studi pendidikan matematika (Aminah, 2014; Kauffman et al., 2002; Norman, 2011; Osana et al., 2006).

Kemampuan SP dalam merumuskan RPP pada aspek KMIP, KMKS, UM, dan KM memberikan pengaruh terhadap kemampuan dalam menyusun antisipasi pedagogis-didaktis. Temuan ini didasarkan hasil wawancara yang dilakukan kepada dua subjek yang diambil secara acak sederhana pada SPM-A dan SnP-C. Peneliti bertanya tentang kesulitan yang dihadapi oleh siswa berdasarkan pengalaman mengajar materi SPLDV kepada kedua subjek yang terpilih. Mereka ditanyakan antisipasi didaktis-pedagogis ketika mengajarkan materi SPLDV. Potongan transkip wawancara kedua subjek (SPM-A-7 dan SnP-C-1) disajikan sebagai berikut.

Peneliti: "Berdasarkan pengalaman Bapak ketika mengajar, apakah pernah menemukan kesulitan atau hambatan yang dialami oleh siswa dalam materi SPLDV?"

SPM-A-7: "Pernah, saya pernah menemukan siswa saya kesulitan dalam materi SPLDV, diantaranya: kesulitan siswa memahami konsep variabel, dan penyelesaian SPLDV menggunakan metode grafik".

Peneliti: "Seperti apa kesulitannya?"

SPM-A-7: "Saya memberikan soal cerita tentang harga baju dan celana. Dalam soal itu, siswa diminta untuk menentukan masing-masing harga baju dan celana."

Peneliti: "Maksudnya?"

SPM-A-7: "Kan di soal cerita diuraikan di toko pakaian yang sama, Ibu Ani dan Ibu Juni membeli baju dan celana yang sama. Ibu Ani membeli 4 baju dan 5 celana seharga sekian (SPM-A7 tidak menceritakan soal secara detail), dan Ibu Juni membeli 3 baju dan 2 celana dengan harga sekian. Berapa harga masing-masing baju"
Peneliti: "Berdasarkan pengalaman Bapak/ lbu ketika mengajar, apakah pernah menemukan kesulitan atau hambatan yang dialami oleh siswa dalam materi SPLDV?"

SnP-C-1: "Ya, ketika itu ada siswa kesulitan dalam materi SPLDV".

Peneliti: "Kesulitannya apa bisa dijelaskan lebih detail?"

SnP-C-1: "Suka ada saja siswa yang salah dalam menyelesaikan soal cerita SPLDV"

Peneliti: Salah dalam menjawab karena kesalahan konsep atau kesalahan prosedur?"

SnP-C-1: "Mungkin..... (5 detik terdiam) bisa duaduanya (SnP-C-1 terlihat tidak yakin dengan argumentasinya)"

Peneliti: "Nah... berdasarkan pengalaman itu, bagaimana cara mengatasinya?"

SnP-C-1: "Diberikan contoh cara menyelesaikan soal cerita SPLDV, siswa bisa belajar dari situ!" (Kode, ${ }^{* * *}$ ) 
Peneliti: "Oh, lantas kesulitannya?"

SPM-A-7: "Ya, sulit mereka... mereka selalu salah dalam pemisalan, dengan memisalkan baju adalah $x$ dan celana adalah $y^{\prime \prime}$.....(kode, *)

Peneliti: "Mengapa salah dengan pemisalan itu?"

"Salah (dengan tegas menjawab), seharusnya siswa memisalkan $x$ adalah harga baju yang dibeli dan $y$ adalah harga celana yang dibeli... bukan hanya baju adalah $x$ dan celana adalah $y "$.

Peneliti: "Lantas berdasarkan pengalaman itu, bagaimana cara mengatasinya?"

SPM-A-7: "Siswa diperkenalkan terlebih dahulu konsep variabel, sampai siswa paham betul apakah yang dimaksud dengan variabel itu..... lalu definisi persamaan, terutama persamaan linier, apa syarat perlu dan syarat cukup persamaan linier, ulas kembali materi persamaan linier satu variabel dan sistem persamaan linier satu variabel" .....(kode, **)

Berdasarkan transkip wawancara sebagaimana disajikan pada bagian sebelumnya, terlihat bahwa SPM-A-7 memiliki pengetahuan materi matematika dengan baik, khususnya konsep variabel (terlihat pada kode *). Selain itu, SPM-A-7 memiliki pengetahuan tentang kesulitan siswa ketika mempelajari SPLDV berdasarkan pengalaman mengajarnya, serta mampu membuat antisipasi didaktis-pedagogis terhadap kesulitan siswa melalui penyesuaian materi dengan kemampuan siswa, urutan materi, dan kelengkapan materi (terlihat pada kode ${ }^{* *}$ ). Sebaliknya, SnP-C-1 tidak secara detail membuat antisipasi didaktis-pedagogis dengan baik (terlihat pada kode ${ }^{* * *}$ ). Temuan tersebut mengindikasikan bahwa lama mengajar tidak berbanding lurus dengan kemampuan dalam KMKS, $\mathrm{UM}$, dan KM, serta merumuskan antisipasi pedagogis-didaktis.

Antisipasi didaktis-pedagogis dapat digunakan mengatasi kesulitan belajar siswa. Pendekatan pembelajaran yang dilakukan guru dalam menyampaikan materi berpotensi menyebabkan siswa sulit memahami matematika (Palpialy \& Nurlaelah, 2015), guru harus mempersiapkan seperangkat antisipasi kesulitan siswa (Lestari et al., 2020), ketika guru menyusun RPP harus bisa mengantisipasi kesulitan belajar siswa secara didaktis maupun pedagogis (Fauzi \& Suryadi, 2020). Antisipasi didaktis merupakan keterkaitan antara prakonsepsi siswa dengan materi (Lestari et al., 2020). Merancang dan menyusun rencana pembelajaran merupakan salah satu kompetensi pedagogis guru. Guru harus bisa membayangkan situasi pembelajaran secara ketika menyusun RPP (Fauzi \& Suryadi, 2020).

\section{Komponen RPP pada Aspek Kegiatan Pembelajaran}

Analisis RPP pada aspek kegiatan pembelajaran yang telah disusun oleh subjek penelitan disajikan pada Tabel 4.

Tabel 4. Analisis RPP pada aspek kegiatan pembelajaran

\begin{tabular}{|c|c|c|c|c|c|c|c|}
\hline \multirow{2}{*}{ Subaspek } & \multirow{2}{*}{$\begin{array}{c}\text { Skor } \\
\text { Maksimal } \\
\text { Ideal (SMI) }\end{array}$} & \multicolumn{6}{|c|}{ Rerata skor } \\
\hline & & SPM-A & SPM-B & SPM-C & SPnM-B & SPnM-C & $\mathrm{SnP}-\mathrm{C}$ \\
\hline $\begin{array}{l}\text { Ketepatan pemilihan model/ } \\
\text { pendekatan pembelajaran } \\
\text { (PMPP) }\end{array}$ & 2 & 2,00 & 2,00 & 2,00 & 2,00 & 2,00 & 2,00 \\
\hline $\begin{array}{l}\text { Sintaks pembelajaran } \\
\text { (STPM) }\end{array}$ & 2 & 2,00 & 2,00 & 2,00 & 1,00 & 1,15 & 1,50 \\
\hline $\begin{array}{ll}\text { Tahapan } & \text { kegiatan } \\
\text { Pembelajaran (TKPM) }\end{array}$ & 2 & 2,00 & 2,00 & 2,00 & 2,00 & 2,00 & 2,00 \\
\hline $\begin{array}{ll}\text { Penerapan } & \text { pengalaman } \\
\text { pembelajaran (PPPM) }\end{array}$ & 2 & 1,70 & 1,92 & 1,88 & 1,00 & 1,31 & 1,00 \\
\hline
\end{tabular}


Pada subaspek ketepatan pemilihan model/pendekatan pembelajaran (PMPP) semua subjek penelitian memiliki skor yang sempurna. Hal ini dikarenakan pemilihan model atau pendekatan pembelajaran sesuai dengan $\mathrm{KD}$, karakteristik materi dan siswa sesuai yang diamanatkan dalam Kurikulum 2013 (Lampiran Peraturan Menteri Pendidikan dan Kebudayaan Nomor 22 Tahun 2016) yakni penggunaan pendekatan saintifik dalam pembelajaran matematika. Pendekatan saintifik merupakan suatu proses pembelajaran yang dilakukan oleh siswa melalui kegiatan mengamati terhadap situasi masalah, merumuskan masalah berdasarkan tahap mengamati, merumuskan hipotesis berdasarkan asumsi-asumsi perumusan masalah, mengumpulkan dan menganalisis data diakhiri menarik pembentukan konsepsi pengetahuan. Namun demikian, ketika ditelaah lebih mendalam pada aspek STPM, langkah-langkah atau prosedur kegiatan pembelajaran yang dijalankan sesuai dengan prosedur teoritik dari pendekatan saintifik hanya terdapat pada RPP yang dibuat oleh SPM. Hal ini ditunjukan dengan pencapaian rerata skor STPM untuk SPM-A, SPM-B, dan SPM-C sama dengan skor maksimal ideal. Sebaliknya, pencapaian rerata skor STPM untuk SPnM-B, SPnM-C, dan SnP-C di bawah 85\% dari SMI. Pencapaian rerata skor di bawah $85 \%$ dari SMI disebabkan oleh masih ditemukan kesalahan dalam menyusun langkah-langkah atau prosedur kegiatan pembelajaran yang dijalankan sesuai dengan prosedur teoritik dari pendekatan saintifik.

Meskipun pada subaspek STPM masih ditemukan pencapaian retara skor di bawah SMI, pada subaspek TKPM subjek penelitian pada semua kategori pencapaian rerata skornya $100 \%$ dari SMI. RPP dari subjek penelitian pada semua kategori pada TKPM memuat kegiatan pembelajaran mencakup tahapan pendahuluan, proses pembentukan pengetahuan, dan tahapan penutup. Akan tetapi, pada subaspek PPPM pencapaian rerata skor di atas $85 \%$ dari SMI hanya diperoleh subjek penelitian pada kategori SPM-A, SPM-B, dan SPM-C. Pencapaian rerata skor di atas $85 \%$ dari SMI dikarenakan langkah-langkah pembelajaran mencerminkan pembelajaran yang didasarkan kepada aktivitas doing mathematics. Pencapaian rerata skor PPPM untuk SPnM-B, SPnM-C, dan SnP-C di bawah $85 \%$ dari SMI, yang dikarenakan langkah-langkah pembelajaran kurang mencerminkan pembelajaran yang didasarkan kepada aktivitas doing math atau pembelajaran masih bersifat transformatif. Temuan ini mengindikasikan bahwa proses pembelajaran matematika menggunakan pendekatan saintifik berkorelasi positif dengan aktivitas doing mathematics.

Selama pembelajaran matematika berlangsung siswa harus melakukan doing mathematics (Twigg, 2011). Misalkan siswa menyelesaikan soal rutin secara berkali-kali menggunakan prosedur rutin, apakah siswa tersebut tidak sedang melakukan doing mathematics? Namun, ketika siswa memperhatikan pola baru saat melakukan prosedur rutin serta membuat koneksi dengan konsep matematika lain saat melakukan komputasi rutin. Dalam situasi tersebut, apakah siswa dapat dikatakan sedang melakukan doing mathematics? Istilah doing mathematics ekivalen dengan aktivitas matematis yang dilakukan oleh siswa ketika menyelesaikan tugas atau masalah matematis (Brandt et al., 2016). Aktivitas matematis melibatkan berbagai keterampilan dan pendekatan yang berbeda, misalnya keterampilan komputasi, strategi prosedural, penalaran logis, representasi simbolik, dan keterampilan pemecahan masalah. Dengan demikian, aktivitas siswa dalam belajar matematika mirip dengan aktivitas yang dilakukan matematikawan, termasuk mencari pola, investigasi, berkomunikasi, mengeksplorasi ide, menemukan notasi, memvisualisasikan hubungan, dan membuat dugaan (Cuoco et al., 1996). Oleh karena itu, tujuan utama dalam kurikulum matematika adalah untuk membantu siswa berkembang serta mahir secara matematis, yang memadukan lima keahian matematis (Kilpatrick et al., 2002). Aktivitas pembelajaran yang akan dipilih oleh guru sangat dipengaruhi oleh keyakinan guru terhadap matematika. Sebagai contoh, jika keyakinan guru terhadap matematika yang berorientasi kepada komputasional maka aktivitas pembelajaran akan difokuskan terhadap pengembangan kemampuan prosedural. Dengan demikian, keyakinan (belifs) guru memberikan pengaruh terhadap penyusunan rencana kegiatan pembelajaran. 


\section{Komponen RPP pada aspek Evaluasi}

Analisis RPP pada aspek evaluasi yang telah dikumpulkan oleh subjek penelitan disajikan pada Tabel 5, terlihat bahwa pencapaian rerata skor SPM-A, SPM-B, dan SPM-C untuk subaspek KETP di atas $85 \%$ dari SMI, sedangkan pencapaian rerata skor KETP SPnM-B, SPnM-C, dan SnPC di bawah $85 \%$ dari SMI. Pencapaian rerata skor KETP di atas $85 \%$ dari SMI disebabkan dalam komponen RPP metode dan teknik evaluasi telah sesuai dengan materi dalam kompetensi dasar yang akan dicapai. Kompetensi dasar yang akan dicapai mencakup aspek pengetahuan (misalnya, berpikir kritis), dan keterampilan (misalnya, penggunaan alat ukur, dan melakukan investigasi atau berbasis masalah). Meskipun demikian, pencapaian rerata skor pada subaspek CE dan KKE subjek penelitian pada semua kategori mencapai skor maksimal ideal (SMI). Hal ini dikarenakan dalam RPP yang dikumpulkan oleh semua subjek penelitian memuat penilaian mencakup semua aspek pengetahuan dan keterampilan, serta komponen evaluasi dalam RPP meliputi kisi-kisi, soal yang diujikan, kunci jawaban, soal yang memuat pengetahuan keterampilan, dan rubrik penskorannya.

Tabel 5. Analisis RPP pada aspek evaluasi

\begin{tabular}{lcccccccc}
\hline \multirow{2}{*}{ Subaspek } & $\begin{array}{c}\text { Skar } \\
\text { Maksimal }\end{array}$ & \multicolumn{7}{c}{ Rerata skor } \\
\cline { 6 - 9 } & Ideal (SMI) & SPM-A & SPM-B & SPM-C & SPnM-B & SPnM-C & SnP-C \\
\hline $\begin{array}{l}\text { Kesesuaian Evaluasi dengan } \\
\text { tujuan pembelajaran (KETP) }\end{array}$ & 2 & 1,90 & 2,00 & 2,00 & 1,50 & 1,23 & 1,00 \\
\hline Cakupan evaluasi (CE) & 2 & 2,00 & 2,00 & 2,00 & 2,00 & 2,00 & 2,00 \\
\hline $\begin{array}{l}\text { Kelengkapan Komponen } \\
\text { Evaluasi (KKE) }\end{array}$ & 2 & 2,00 & 2,00 & 2,00 & 2,00 & 2,00 & 2,00 \\
\hline
\end{tabular}

Mengacu uraian yang telah dikemukakan pada bagian sebelumnya, kemampuan pedagogis khususnya kemampuan menyusun RPP sangat dipengaruhi oleh kualifikasi pendidikan guru bukan ditentukan oleh lama mengajar. Meskipun demikian, kemampuan pegagogis guru dalam konteks penyusunan RPP diluar kualifikasi pendidikan dapat ditingkatkan, diantararanya melalui: suvervisi akademik dengan pola pendampingan (Hartini, 2021); bimbingan berkelompok (Santosa, 2020); inhouse traning (Jayadipura, 2018; Kamaludin, 2021); melalui workshop (Hartini, 2021). Namun demikian, pelatihan guru tidak mempengaruhi terhadap aspek pengetahuan tetapi pada aspek keterampilan (Pratama \& Lestari, 2020). Temuan penelitian sebagaimana telah diuraikan sebelumnya tidak mengindikasikan bahwa kualitas pengajaran matematika yang dilakukan oleh SPnM dan SnP sebelum dilakukan penelitian tidak bagus dan tidak efektif, melainkan dengan waktu yang dibatasi (selama 60 menit) oleh peneliti dalam menyusun RPP pada kompetensi dasar yang dipilih (KD 3.3 dan 4.3) menyebabkan kemampuan menyusun RPP SPnM dan SnP tidak lebih baik dibandingkan dengan SPM.

Hasil observasi pengetahuan matematika guru (disingkat, PMG) dalam materi SPLKDV yang dimiliki subjek penelitian ketika menyusun RPP disajikan pada Tabel 6.

Tabel 6. PMG subjek penelitian dalam menyusun RPP

\begin{tabular}{lcccccc}
\hline \multirow{2}{*}{ PMG } & \multicolumn{7}{c}{ Subjek penelitian yang diamati } \\
\cline { 2 - 8 } & SPM-A & SPM-B & SPM-C & SnPM-B & SnPM-C & SnP-C \\
\hline PKU & $\times$ & $\times$ & $x$ & $x$ & $x$ & $\times$ \\
\hline PKK & $\times$ & $\times$ & $x$ & - & - & - \\
\hline PKoH & $\times$ & $x$ & $x$ & - & $x$ & $\times$ \\
\hline PMS & $\times$ & $\times$ & $x$ & - & $x$ & - \\
\hline PtMM & $\times$ & $\times$ & $x$ & - & - & - \\
\hline PtMK & $\times$ & $x$ & $x$ & $x$ & $x$ & $\times$ \\
\hline
\end{tabular}

Berdasarkan Tabel 6 terlihat bahwa SPM memiliki semua domain PMG yang diperlukan dalam menyusun RPP. Pada subdomain PKU (pengetahuan keterampilan umum), dan PtmK (pengetahuan matematika yang berkaitan dengan persyaratan kurikulum) dikuasai oleh SP pada semua kategori kualifikasi pendidikan dan lama mengajar (SPM-A, SPM-B. SPM-C, SnPM-B, SnPM$\mathrm{C}$ dan $\mathrm{SnP}-\mathrm{C}$ ). Namun pada subdomain PKK (pengetahuan dan keterampilan matematika yang diperlukan dalam mengajar), dan PtMM (pengetahuan tentang apa dan bagaimana guru 
mengurutkan matematika dan kegiatan pembelajaran) hanya dimiliki oleh SP dengan kualifikasi sarjana pendidikan matematika pada semua kategori lama mengajar (SPM-A, SPM-B, dan SPM-C), hal ini disebabkan oleh pengetahuan matematika yang mumpuni yang diperoleh SPM ketika pengalaman belajar di LPTK. Selanjutnya, lama mengajar di atas lima tahun (Kode, B dan C) memberikan dampak terhadap $\mathrm{PKoH}$ (pengetahuan matematika dikaitkan dengan topik matematika di sekolah) pada SnPM dan SnP.

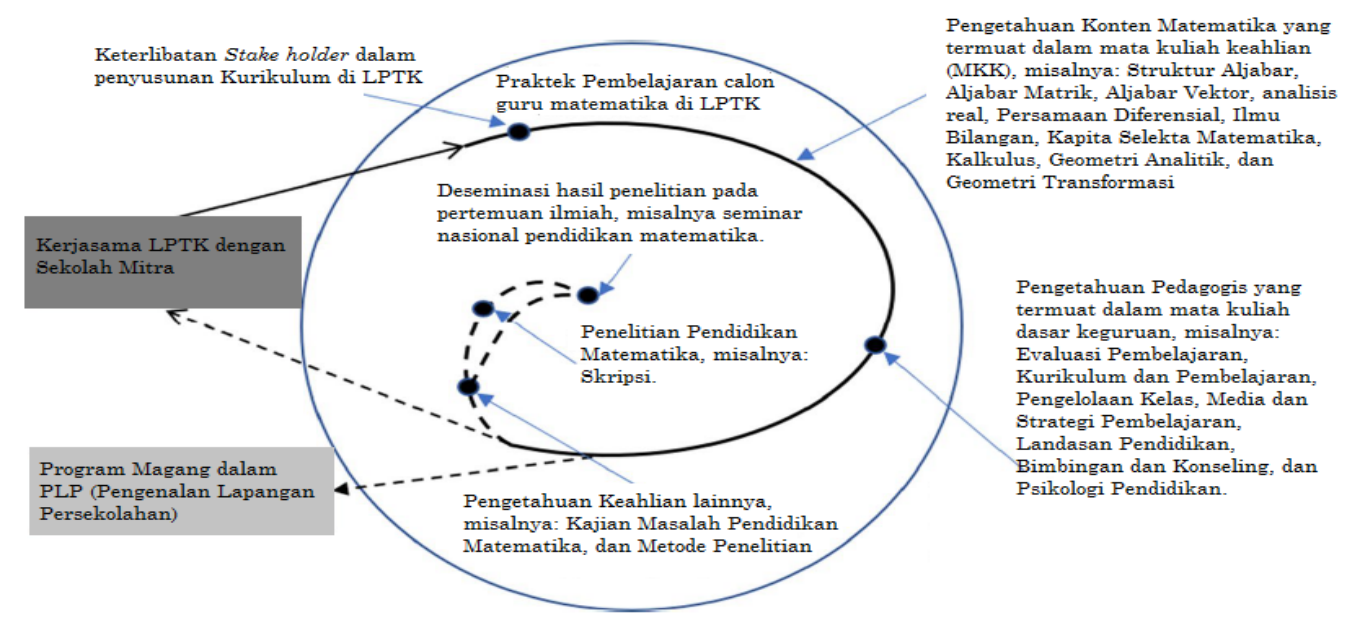

Gambar 2. Praktek pembelajaran calon guru matematika di LPTK

Gambar 2 mengilustrasikan praktek pembelajaran calon guru matematika di LPTK yang terdiri dari beberapa interaksi kegiatan belajar memuat: pengetahuan konten matematika, pengetahuan pedagogik, pengalaman belajar profesi guru dalam pengenalan lapangan persekolahan, dan penelitian pada bidang pendidikan matematika. Pembelajaran tentang konten matematika, struktur pembelajaran, dan proses mengajar dalam program magang yang dibingkai dalam kurikulum pada program studi pendidikan matematika akan mendukung profesionalisme guru (da Ponte et al., 2017). Calon guru matematika (SPM) memasuki memulai lintasan belajar dalam praktek pembelajaran secara teoritis dan praktis, mulai sebagai pelajar, program magang, dan penelitian dalam proporsi yang berbeda-beda. Calon guru matematika (SPM) sebagai bagian dari pengalaman belajar mereka, belajar dalam domain pengetahuan yaitu pengetahuan konten matematika, dan pengetahuan pedagogis serta pengetahuan lainnya yang diperlukan dalam menunjang profesionalisme guru. Dengan demikian, praktek pembelajaran calon guru matematika di LPTK (SPM) memberikan dampak secara signifikan terhadap pengetahuan matematika guru.

\section{KESIMPULAN}

Kemampuan guru dalam merumuskan tujuan pembelajaran (menyusun indikator pembelajaran sesuai dengan kata kerja operasional yang memuat audience, behavior, content, dan degre), mengidentifikasi materi matematika (kesesuaian materi dengan kemampuan siswa, mengurutkan materi dari sederhana sampai kompleks, dan kelengkapan materi), membuat antisipasi didaktis-pedagogis dalam kegiatan pembelajaran, menciptakan kegiatan pembelajaran matematika yang memuat aktivitas matematika (doing mathematics) dalam komponen RPP sangat dipengaruhi oleh kualifikasi pendidikan dibandingkan dengan lama mengajar, dan praktek pembelajaran calon guru matematika di LPTK (SPM) memberikan dampak secara signifikan terhadap pengetahuan matematika guru.

\section{REKOMENDASI}

Kualitas pembelajaran matematika sangat dipengaruhi oleh pengetahuan matematika guru, salah satunya melalui penyusunan rencana pelaksanaan pembelajaran. Untuk meningkatkan profesionalisme guru matematika dapat dilakukan dengan penguatan pendidikan calon guru yang 
dilakukan oleh Lembaga Pendidikan Tenaga Kependidikan maupun pengembangan dan peningkatan profesi guru, misalnya melalui workshop, in-house training, maupun pelatihan untuk guru lainnya yang difokuskan tidak hanya kepada peningkatan keterampilan tetapi juga pengetahuan matematika.

\section{UCAPAN TERIMAKASIH}

Ucapan terima kasih kepada para guru matematika di Kota Bogor yang terlibat dalam kegiatan penelitian yang tidak bisa disebutkan satu persatu. Tetap semangat dalam mengabdi demi kemajuan bangsa dan negara ditengah situasi darurat pandemi Covid-19.

\section{DAFTAR PUSTAKA}

Alhikmah, R. N., Roza, Y., \& Maimunah, M. (2021). Analisis kesulitan guru matematika SMP dalam menyusun Rencana Pelaksanaan Pembelajaran (RPP) berdasarkan kurikulum 2013. Jurnal Cendekia: Jurnal Pendidikan Matematika, 5(1), 655-669. https://doi.org/10.31004/cendekia.v5i1.433

Aminah, N. (2014). Analisis kemampuan pedagogik dan self confidence calon guru matematika dalam menghadapi praktek pengalaman lapangan. Euclid, 1(1), 55-59. https://doi.org/10.33603/e.v1i1.344

Ball, D. L., Thames, M. H., \& Phelps, G. (2008). Content knowledge for teaching: what makes it special?. Journal of Teacher Education, 59(5), 389-407. https://doi.org/10.1177/0022487108324554

Bowie, L., Venkat, H., \& Askew, M. (2019). Pre-service primary teachers' mathematical content knowledge: an exploratory study. African Journal of Research in Mathematics, Science and Technology Education, 23(3), 286-297. https://doi.org/10.1080/18117295.2019.1682777

Brandt, J., Lunt, J., \& Meilstrup, G. R. (2016). Mathematicians' and math educators' views on "doing mathematics." Primus, 26(8), 753-769. https://doi.org/10.1080/10511970.2016.1166408

Campbell, P. F., Nishio, M., Smith, T. M., Clark, L. M., Conant, D. L., Rust, A. H., DePiper, J. N., Frank, T. J., Griffin, M. G., \& Choi, Y. (2014). The relationship between teachers'mathematical content and pedagogical knowledge, teachers' perceptions, and student achievement. Journal for Research in Mathematics Education, 45(4), 419-459. https://doi.org/10.5951/jresematheduc.45.4.0419

Chen, S., \& Zhang, B. (2019). Improving prospective teachers' lesson planning knowledge and skills through lesson study. In R. Huang, A. Takahasi, \& J. da Ponte (Eds.), Theory and practice of lesson study in mathematics (pp. 549-575). Switzerland: Springer Nature. https://doi.org/10.1007/978-3-030-04031-4_27

Cuoco, A., Paul Goldenberg, E., \& Mark, J. (1996). Habits of mind: An organizing principle for mathematics curricula. Journal of Mathematical Behavior, 15(4), 375-402. https://doi.org/10.1016/S0732-3123(96)90023-1

da Ponte, J. P., Santos, L., Oliveira, H., \& Henriques, A. (2017). Research on teaching practice in a Portuguese initial secondary mathematics teacher education program. ZDM - Mathematics Education, 49(2), 291-303. https://doi.org/10.1007/s11858-017-0847-7 
Döhrmann, M., Kaiser, G., \& Blömeke, S. (2012). The conceptualisation of mathematics competencies in the international teacher education study TEDS-M. ZDM - International Journal on Mathematics Education, 44(3), 325-340. https://doi.org/10.1007/s11858-012-0432-z

Fauzi, I., \& Suryadi, D. (2020). Didactical design research untuk mengembangkan kompetensi pedagogik guru di sekolah dasar. Inventa, 4(1), 58-68. https://doi.org/10.36456/inventa.4.1.a2207

Hartini, H. (2021). Meningkatkan kemampuan guru dalam menyusun rencana pelaksanaan pembelajaran (RPP) melalui kegiatan workshop. Jurnal Pedagogiana, 8(49), 1-12.

Herdawati, H., Rochaminah, S., \& Paloloang, B. (2019). Kemampuan guru matematika dalam merencanakan dan melaksanakan pembelajaran Di SMA Negeri 3 Palu. Aksioma, 8(1), 63-71. https://doi.org/10.22487/aksioma.v8i1.204

Hidayat, A. F. (2020). Identifikasi Kesulitan guru matematika dalam mengimplementasikan kurikulum 2013. Aksioma, 9(1), 42-50.

Jayadipura, Y. (2018). In house training untuk meningkatkan kemampuan guru dalam menyusun RPP. IDAARAH, 2(2), 260-268.

Kamaludin, J. (2021). Pelaksanaan in-house training (IHT) untuk meningkatkan kemampuan guru dalam menyusun RPP. Jurnal Pedagogiana, 8(49), 1-12.

Kauffman, D., Johnson, S. M., Kardos, S. M., Liu, E., \& Peske, H. G. (2002). "Lost at sea": New teachers' experiences with curriculum and assessment. Teachers College Record, 104(2), 273-300. https://doi.org/10.1111/1467-9620.00163

Kilpatrick, J., Swafford, J., \& Findell, B. (2002). Helping children learn mathematics. In Helping Children Learn Mathematics. https://doi.org/10.17226/10434

Lappan, G., \& Friel, S. N. (1993). Implementing the "professional standards for teaching mathematics": what do we have and where do we go from here? The Arithmetic Teacher, 40(9), 524-526.

Lestari, Y. N., Sugiatno, \& Hartoyo, A. (2020). Antisipasi didaktis berstruktur konflik kognitif untuk mengatasi hambatan belajar siswa dalam materi penjumlahan dan pengurangan bilangan bulat. AlphaEuclidEdu, 1(1).

Norman, P. (2011). Planning for what kind of teaching? Supporting cooperating teachers as teachers of planning. Teacher Education Quarterly, 38(3), 49-68. http://files.eric.ed.gov/fulltext/EJ940633.pdf

Norton, S. (2019). The relationship between mathematical content knowledge and mathematical pedagogical content knowledge of prospective primary teachers. Journal of Mathematics Teacher Education, 22(5), 489-514. https://doi.org/10.1007/s10857-018-9401-y

Osana, H. P., Lacroix, G. L., Tucker, B. J., \& Desrosiers, C. (2006). The role of content knowledge and problem features on preservice teachers' appraisal of elementary mathematics tasks. Journal of Mathematics Teacher Education, 9(4), 347-380. https://doi.org/10.1007/s10857-0064084-1 
Palpialy, J. J., \& Nurlaelah, E. (2015). Pengembangan desain didaktis materi pecahan pada sekolah $\begin{array}{lllll}\text { menengah pertama (SMP). Jurnal Matematika Integratif, } 11(2), & 127 .\end{array}$ https://doi.org/10.24198/jmi.v11.n2.9425.127-136

Pratama, L. D., \& Lestari, W. (2020). Pengaruh pelatihan terhadap kompetensi pedagogik guru matematika. Jurnal Cendekia: Jurnal Pendidikan Matematika, 4(1), 278-285. https://doi.org/10.31004/cendekia.v4i1.207

Santosa, E. R. (2020). Upaya meningkatkan kemampuan guru dalam membuat RPP berbasis high order thingking skill (HOTS) melalui bimbingan berkelompok. PAJAR (Pendidikan Dan Pengajaran), 4(2), 338-346.

Siregar, D. (2019). Peningkatan kemampuan guru dalam melaksanakan. Aksioma, 8(1), 1-12.

Tatto, M. T., Ingvarson, L., Schwille, J., Peck, R., Senk, S. L., \& Rowley, G. (2008). Teacher education and development study in mathematics (TEDS-M): policy, practice, and readiness to teach primary and secondary mathematics. Conceptual Framework. In International Association for the Evaluation of Educational Achievement. East Lansing, Ml: Teacher Education and Development International Study Center, College of Education, Michigan State University. http://eric.ed.gov/?id=ED542390

Twigg, C. A. (2011). The math emporium: a silver bullet for higher education. Change: The Magazine of Higher Learning, 43(3), 25-34. https://doi.org/10.1080/00091383.2011.569241

Yin, R. K. (2018). Case study research and applications: Design and methods. In Journal of Hospitality \& Tourism Research (Vol. 53, Issue 5). Los Angeles: SAGE Publications, Inc. https://doi.org/10.1177/109634809702100108 